\title{
Application of Altman Modified Z-Score to Predict Financial Distress in the Indonesian Telecommunications Industry
}

\author{
Rianti Fifriani ${ }^{1}$, Perdana Wahyu Santosa ${ }^{2}$ \\ ${ }^{1}$ Faculty of Economics and Business, Universitas YARSI, Jakarta \\ ${ }^{2}$ Program Master of Management, School of Graduate Studies, Universitas YARSI, Jakarta

\section{Article} \\ Information \\ History of article: \\ Received: 10-04-2019 \\ Approved: 25-06-2019 \\ Published: 30-06-2019 \\ Keywords: \\ Telecommunication, \\ financial distress, \\ bankruptcy, Altman \\ modified Z-Score

\begin{abstract}
Bankruptcy prediction is needed to assess the prospect of going concern and sustainability of the corporations in the future. This study aims to predict the bankruptcy of corporates with the Altman Z-Score Modification model in the telecommunications industry in Indonesia. The data used are the financial statements of the telecommunications industry that listing on the Indonesia Stock Exchange for the period 2011-2015. Samples for this study uses purposive sampling according to company criteria. The results of the study using the Altman Z-score modification method found two potentially bankrupt companies, namely Bakrie Telecom, Tbk, and Smartfren, Tbk. While Indosat, Tbk, and $X L$ Axiata, Tbk have high financial distress potential due to liquidity and profitability problems that tend to weaken. Meanwhile, Telkom Indonesia, Tbk, and Infracom Inovisi financial concessions are relatively healthy and have the
\end{abstract} \\ right business expectations
}

\begin{abstract}
Abstrak
Prediksi kebangkrutan diperlukan untuk menilai prospek going concern perusahaan di masa depan. Studi ini bermaksud untuk memprediksi kebangkrutan perusahaan dengan model Altman Modifikasi Z-Score pada industri telekomunikasi di Indonesia. Data yang digunakan adalah laporan finansial emiten industri telekomunikasi di Bursa Efek Indonesia periode 2011-2015. Sampel studi ini menggunakan purposive sampling sesuai kriteria perusahaan. Hasil penelitian yang menggunakan metode Altman modifikasi z-score menemukan dua perusahaan berpotensi bangkrut, yaitu Bakrie Telecom, Tbk dan Smartfren, Tbk. Sedangkan Indosat, Tbk dan XL Axiata, Tbk memiliki potensi financial distress yang tinggi karena masalah likuiditas dan profitabilitas yang cenderung melemah. Sedangkan kondisi finansial Telkom Indonesia, Tbk dan Inovisi Infracom, Tbk tergolong sehat dan memiliki ekspektasi bisnis yang baik.
\end{abstract}

\section{INTRODUCTION}

Financial problems experienced by the company characterizes corporate bankruptcy, generally starting from liquidity problems and then solvency. If management does not immediately pay attention to the financial problems, the company will experience financial distress and then profoundly in bankruptcy problems and liquidation (Fithri, 2010; Santosa, 2011). Companies that financially default are companies that are unable to pay their obligations at maturity even though the total assets exceed their total liabilities (Fifrianti \& Santosa, 2018; Van Horne \& Wachowics, 2011).

The dynamics of a company's financial performance are influenced by an increasingly turbulent business environment and increasingly fierce competition. Changes in the 
telecommunications business environment in Indonesia depend on political, economic, social, and information technology dynamics. Companies that are unable to adapt to changing environments will experience business problems and investment risks. Companies always face various risks, especially business risks, financial risks, and country risks that often create financial distress and bankruptcy (Fifrianti \& Santosa, 2018). Bankruptcy or bankruptcy of a company usually begins with financial distress that begins with income uncertainty, inventory problems, uncollectible receivables, and assets turnover to decreased profitability (Santosa, 2010). Predictions about the company's financial condition, related to bankruptcy, are essential information for stakeholders, namely creditors, investors, regulatory authorities, auditors, and management (Butet, 2012).

Financial distress is a stage of the declining financial condition of a company before bankruptcy. For this reason, an early introduction to the condition of companies experiencing financial distress is essential. Earlier information about the financial distress conditions in the company provides an opportunity for management, owners, investors, regulators, and other stakeholders to make consistent efforts (Brigham \& Houston, 2016). Management and owners have an interest in making efforts to prevent more severe conditions towards bankruptcy. Investors have an interest in making an investment or divestment decisions and capital structure restructuring (Subrahmanyam, 2014).

Fifrianti \& Santosa (2018) stated that financial distress conditions could be identified earlier before they occur by using an early warning system model. This model can be generally used to identify the symptoms of financial distress in corporations, henceforth management makes efforts to improve capital structure and company liquidity before financial conditions become increasingly critical or bankruptcy (Santosa, 2010). Bankruptcy researches are quite massive, and several of them have developed prediction models that try to help potential investors and creditors in choosing the company where to put their funds so as not to get caught up in the financial distress problem. The prediction models of bankruptcy are among others, put forward by Altman (1968), Springate (1978), Ohlson (1980), and Zmijewski (1983).

Internal and external problems of the company are two crucial things that trigger bankruptcy in a company. According to Fithri (2010), problems from the internal factors are usually caused by the strategies implemented by management, not under market conditions, or the management does not pay close attention to changing market developments, so the profits derived by the company cannot cover their obligations. While problems from the external side, usually triggered by economic conditions in Indonesia and in the world that is still uncertain. The cause of the high risk of a company experiencing financial difficulties or even bankruptcy if the company is not ready to face current developments (Fifrianti \& Santosa, 2018).

The telecommunications industry has a big business and technological risks so that the industry is vulnerable to changes in its business environment, including strict government regulations and favoring SOEs. Besides, the telecommunications industry requires a large investment, rapid technological development, sharp tariff competition, and rapid changes in customer tastes, especially millennials. For example, the case of companies experiencing financial distress is PT. Axis Telecom Indonesia, which merged with XL, as quoted in tribunnews.com (2014), CEO of PT. Axis said that the merger and acquisition of Axis by XL was the right step to overcome the company's financial difficulties. Each year, Axis loses Rp2.3 trillion and has been in arrears in paying BHP Frequency obligations. After the approval of the corporate action, Axis is finally willing to pay BHP worth Rp 1 trillion at the end of December 2013.

Financial statements issued by companies are one source of information about the company's financial position, performance, and changes in the company's financial position, which is very useful 
to support the right decision making. Financial data in financial statements are useful to see the condition of the company's financial health.

\section{LITERATURE REVIEW}

The method used in the Altman Model (Z-Score) is Multiple Discriminant Analysis with five main types of financial ratios namely Working Capital to Total Assets, Retained Earnings to Total Assets, Earnings Before Interest and Taxes to Total Assets, Book Value of Equity to Book Value of Debt, and Sales to Total Asset (Brigham \& Houston, 2016). The use of the Altman method is commonly used by practitioners to predict a company's bankruptcy. Besides this method, there are also other methods used to predict financial distress and bankruptcy, namely the Zmijewski Model, and the Springate Model (Subrahmanyan, 2014).

The Springate model is a model developed by Springate (1978) using multidiscriminant analysis, using 40 companies as samples. This model can be used to predict financial distress with an accuracy level of $92.5 \%$. Using the same model and method, Botheras (1979) obtained results with an accuracy rate of $88 \%$. Sands (1980) conducted a test with an accuracy rate of $83 \%$ (Fanny and Saputra 2000). The Springate Model (S-Score) uses multidiscriminant analysis, with Working Capital to Total Assets, Net Profit Before Interest and Taxes to Total Assets, Net Profit Before Taxes to Current Liabilities, and Sales to Total Assets (Brigham \& Houston, 2016).

\section{Altman Z-Score Model}

Altman discriminant analysis (1968) is one of the statistical, financial techniques that researchers can use to predict the existence of financial distress or bankruptcy of a company. Altman has communicated several ratios into predictive models with statistical techniques, according to Fifrianti and Santosa (2018) are: "The discrimination used to predict bankruptcy is a very well-known term called the Z-Score."

Z-Score is a score determined from the standard calculation times, which shows the probability level of a company's bankruptcy. After researching selected variables and samples, Altman produced the first bankruptcy model. Bankruptcy equation aimed at predicting a public manufacturing company. The equation of the first Altman model is (Altman, 1968):

$$
Z=1,2 X_{1}+1,4 X_{2}+3,3 X_{3}+0,6 X_{4}+0,999 X_{5}
$$

Where:

$$
\begin{aligned}
& Z=\text { Bankruptcy index } \\
& X_{1}=\text { Working Capital/Total Assets } \\
& X_{2}=\text { Retained Earning/Total Assets } \\
& X_{3}=\text { Earnings before Interest and Tax/Total Assets } \\
& X_{4}=\text { Market Value Equity/Book Value of Debt } \\
& X_{5}=\text { Sales/Total Assets }
\end{aligned}
$$

The value of $Z$ is an aggregate index of the multiple discriminant analysis functions. According to Altman, there are cut-off values for the value of $Z$ to illustrate whether the company will experience financial failure or not in the future, which is divided into three categories, namely:

a. If the value of $Z<1.8$, including the bankrupt company.

b. If the value is $1.8<\mathrm{Z}<2.99$, it is included in the gray area (it cannot be determined whether the company is healthy or bankrupt).

c. If the value of $Z>2.99$, including companies that are not bankrupt 


\section{Altman Revised Z-Score}

The Altman model was revised to be more reliable and able to predict financial distress and bankruptcy with a prediction accuracy rate of $95 \%$. The revision made by Altman is an adjustment made so that the bankruptcy prediction model is not only used by manufacturing companies but can also be applied to companies in other sectors. The old model experienced a change in one of the variables used. Altman changed the Market value of equity numerator on X4 to Book value of equity, so the revision model became as follows (Altman et al. 2013):

$$
Z=0,718 X_{1}+0,847 X_{2}+3,107 X_{3}+0,420 X_{4}+0,998 X_{5}
$$

Where:

$$
\begin{aligned}
& \mathrm{Z}=\text { Bankruptcy index } \\
& \mathrm{X}_{1}=\text { Working Capital } / \text { Total Assets } \\
& \mathrm{X}_{2}=\text { Retained Earnings } / \text { Total Assets } \\
& \mathrm{X}_{3}=\text { Earnings before Interest and Tax / Total Asset } \\
& \mathrm{X}_{4}=\text { Book Value of Equity / Book Value of Debt } \\
& \mathrm{X}_{5}=\text { Sales /Total Assets }
\end{aligned}
$$

The classification of a good and bankrupt company is based on the Altman Z-Score value (1983), which is:

a. If the value of $\mathrm{Z}<1.23$, including the bankrupt company.

b. If the value of $1.23<\mathrm{Z}<2.9$ is included in the gray area (it cannot be determined whether the company is healthy or is bankrupt).

c. If the value of $\mathrm{Z}>2.9$, including companies that are not bankrupt.

\section{Altman Modified Z-Score}

Increasingly complex business environment conditions encourage adjustments to various types of companies because their characteristics differ in each sector, Altman then modifies the model again so that it can be applied to all companies, such as manufacturing, non-manufacturing, and bond issuing companies in emerging markets (Fifrianti \& Santosa, 2018). In this Modified Z-Score Altman eliminates variable X5 (sales / total assets), because this ratio is very varied in industries with different asset sizes. The following Z-Score equation is modified by Altman et al. (1995):

$$
Z=6,56 X_{1}+3,26 X_{2}+6,72 X_{3}+1,05 X_{4}
$$

Where:

$$
\begin{aligned}
& \mathrm{Z}=\text { bankruptcy index } \\
& \mathrm{X}_{1}=\text { working capital } / \text { total assets } \\
& \mathrm{X}_{2}=\text { retained earnings } / \text { total assets } \\
& \mathrm{X}_{3}=\text { earnings before interest and taxes / total assets } \\
& \mathrm{X}_{4}=\text { market value of equity / total liabilities }
\end{aligned}
$$

The classification of a good and bankrupt company is based on the Z-score of the Modified Altman model, namely:

a. If the value of $Z<1.1$, including the bankrupt company.

b. If the value of $1.1<\mathrm{Z}<2.6$ is included in the gray area (it cannot be determined whether the company is healthy or bankrupt).

c. If the value of $\mathrm{Z}>2.6$, including companies that are not bankrupt.

\section{Preivous Research}


Previous research related to company bankruptcy, conducted by several previous researchers, including Brimantyo et al. (2013), who found by applying the Altman Z-Score method, the entire company that was the object of research showed an unhealthy financial performance in the 2009-2011 period and potentially bankruptcy. Almost all companies are predicted to go bankrupt because the Z-Score value of the company recorded a value below 1.81. From several companies studied, PT. Smartfren Telecom Tbk has the worst Z-Score because it showed a negative Zscore value for three years in a row in 20092011.

Harnanta \& Idhe (2013), found that the test results using the Altman Z-Score method were obtained during the 2008-2011 period, only PT Telkom Tbk was declared healthy. Whereas for PT Indosat Tbk and PT Bakrie Telecom Tbk only in 2008 were in the "gray area", and in the period 20092011 weakened to the bankruptcy area. Furthermore, for PT. XL Axiata Tbk in 2008 was declared bankrupt, and in 2009 it was categorized as healthy again, but in 2010 and 2011 entered the "gray area" again. Predicted by the Springate method, PT Telkom Tbk in the 2008-2011 period was declared to be in a healthy area. PT XL Axiata Tbk only in the 2009 period entered the healthy area, while in the other period, the bank went back into the bankrupt area. For PT. Indosat Tbk and PT Bakrie Telecom have always been in the area of bankruptcy during the 2008-2011 period.

Other researchers, Kokyung and Khairani (2013), found that Bakrie Telecom Tbk in 20092012 experienced a significant decline in financial performance. This finding in line with the results of the Altman Z-score analysis, which shows the area of bankruptcy or the existence of a severe liquidity problem in 2012. From the results of the bankruptcy prediction analysis conducted at PT. Bakrie Telecom Tbk in 2009-2012 states that the company is threatened with bankruptcy during 2009- 2012. These findings reinforce the analysis of the Springate method, which shows the company is in bankruptcy, also during 2009-2012.

Said (2014) states that the Z-Score value owned by telecommunications companies fluctuates with a range of $Z$ values $<1.81$. Furthermore, use the trend values, which are forecasts in the future, so that these values may still experience an increase or decrease in the value of $Z$ for the next 5,7 , and 9 years. Moreover, from the results of research on the Altman Z-Score method can be applied effectively to predict the potential financial health problems of a company in Indonesia.

Fifrianti and Santosa (2018), who conducted a bankruptcy prediction study in the telecommunications industry using the Springate method for the period 2011-2015, concluded that there were two potentially bankrupt companies, namely PT Bakrie Telecom, Tbk and PT Smartfren, Tbk. While PT Indosat, Tbk, PT XL Axiata, Tbk, and PT Inovisi Infracom, Tbk are quite healthy but still have financial distress risk and bankruptcy potential. While PT Telkom Indonesia, Tbk is classified as very healthy financially.

\section{Conceptual framework}

This bankruptcy study intends to predict the company's financial problems using the Altman Z-score method for telecommunications companies listed on the Indonesia Stock Exchange in the 2011-1015 period. Based on previous theoretical studies, the financial distress analysis is presented in Figure 1 below based on the above model: 


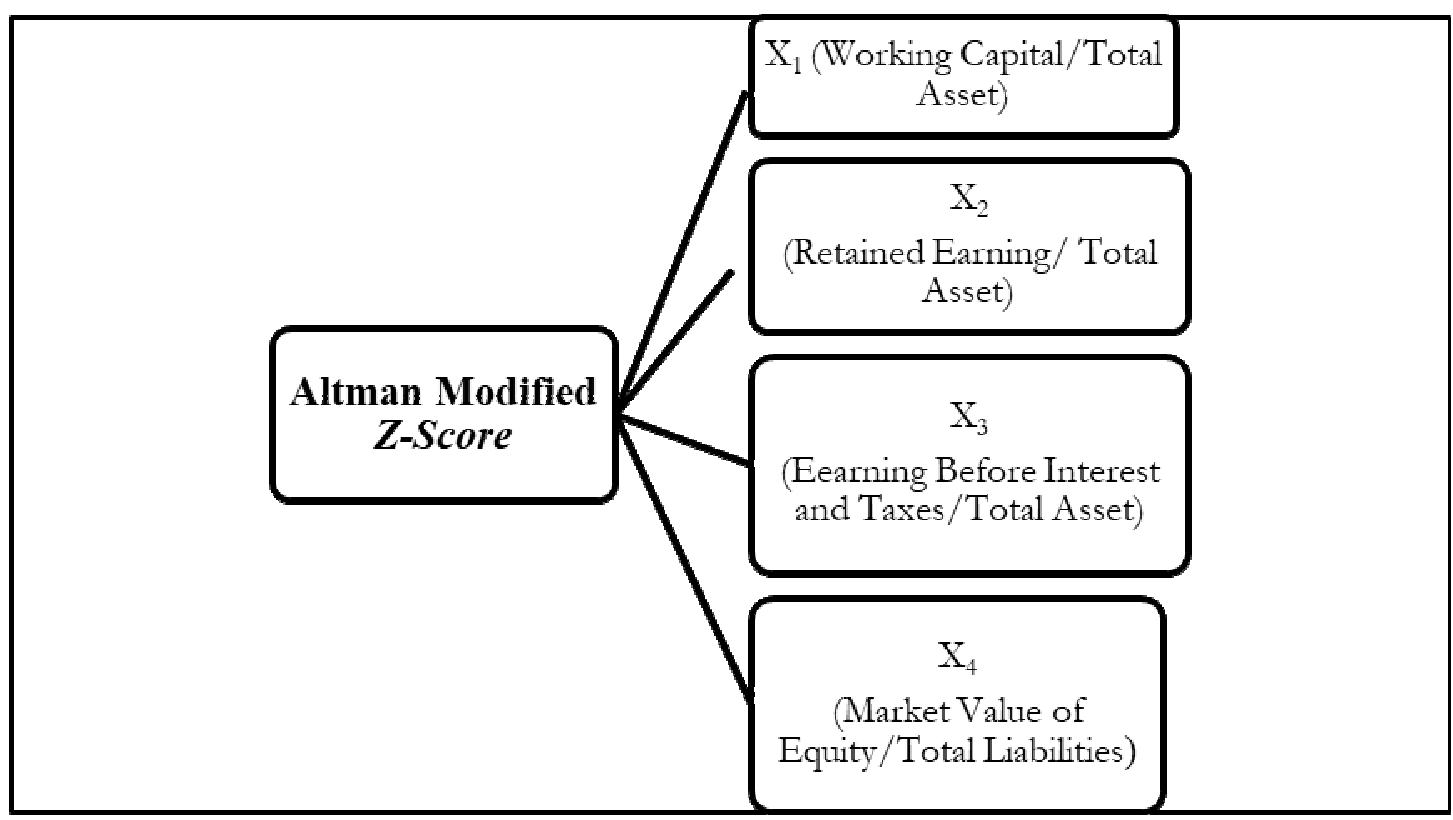

Figure 1. Conceptual Framework of Altman Modified Z-Score

\section{DATA AND METHOD}

\section{Population and Sample}

The population in this study are all telecommunications companies listed on the Indonesia Stock Exchange in the 2011-2015 period. While the sample selection of this study uses purposive sampling to get a representative sample following predetermined criteria. The specified criteria consist of general and specific criteria (Santosa \& Hidayat, 2014).

General criteria are criteria that all samples must meet, namely:

a. Financial data (income statement, balance sheet, and cash flow) are available in full for the 2011-2015 period.

b. Stock price data is available at the last trading date of the year.

\section{Data analysis method}

\section{Altman Modified Z-Score}

The cut-off value used in the Altman model is 2.6, which means that if a company has a Z-Score of more than 2.6, then the company is considered healthy or has no potential for bankruptcy. If the company has a Z-Score less than 1.1, then the company has the potential to experience bankruptcy, and if the company has a Z-Score of more than 1.1 and less than 2.6, then the company is in the gray area or prone to bankruptcy.

\section{ANALYSIS AND DISCUSSION}

\section{Prediction of Altman Modified of Z-Score}

PT Bakrie Telecom, Tbk.

Based on the analysis of the Altman Z-Score Modification method conducted at PT Bakrie Telecom Tbk in the 2011-2015 period, the data processing results show below: The results of the Altman ZScore Modification analysis method at PT Bakrie Telecom, Tbk in the 2011-2015 period showed a decrease in the value of X1 and X2, which means that the liquidity and profitability of PT Bakrie Telecom, Tbk companies in the 2011-2015 period declined. Furthermore, the X3 value of the company decreased from 2011 to 2014 and slightly increased in 2015, which shows that the increased 
ability of the company's assets to generate operating income (earnings from company assets) in 2015. Then, the value of $\mathrm{X} 4$ tends to fluctuate, which means that the value of a company in the eyes of investors in an active market (capital market) fluctuates.

Table 1. Results of Altman Modified Z-Score of PT Bakrie Telecom Tbk.

\begin{tabular}{crrrrr}
\hline Tahun & WCTA $\left(\boldsymbol{X}_{1}\right)$ & RETA $\left(\boldsymbol{X}_{2}\right)$ & EBITTA $\left(\boldsymbol{X}_{3}\right)$ & MVEBVD $\left(\boldsymbol{X}_{4}\right)$ & Z-Score \\
\hline 2011 & $-0,1644$ & $-0,1133$ & $-0,0142$ & 0,9440 & $-0,5522$ \\
2012 & $-0,2326$ & $-0,4997$ & $-0,0553$ & 0,2063 & $-3,3094$ \\
2013 & $-0,5197$ & $-0,7853$ & 0,0004 & 0,1509 & $-5,8082$ \\
2014 & $-0,5988$ & 0,7921 & 0,0005 & 0,1821 & $-5,6384$ \\
2015 & $-0,6246$ & 0,8535 & 0,0004 & 0,1305 & $-6,6966$ \\
\hline
\end{tabular}

Source:The Result of Processed Research Data

The value of the Altman Z-Score method at PT Bakrie Telecom, Tbk, also tends to decrease from 2011 to 2013, which, when viewed from the cut off point of this method is the company potentially experiencing bankruptcy in the 2011-2015 period. The company's liquidity is getting worse due to lower profitability. The low profitability of the company is due to the low operating profit, which causes liquidity problems and the low solvency capability of PT Bakrie Telecom. The results are in-line with Fifrianti and Santosa (2018) conclusions.

PT XL Axiata, Tbk.

Based on the analysis of the Altman Z-Score Modification method conducted at PT XL Axiata Tbk in the 2011-2015 period, the data processing results show below:

Table 2. Results of Altman Modified Z-Score of PT XL Axiata, Tbk.

\begin{tabular}{cccccc}
\hline Tahun & WCTA $\left(X_{1}\right)$ & RETA $\left(X_{2}\right)$ & EBITTA $\left(X_{3}\right)$ & MVEBVD $\left(X_{4}\right)$ & Z-Score \\
\hline 2011 & $-0,1713$ & 0,2383 & 0,1240 & 2,2054 & 2,8015 \\
2012 & $-0,1433$ & 0,2556 & 0,1228 & 2,3560 & 3,1919 \\
2013 & $-0,0518$ & 0,2226 & 0,0412 & 1,7768 & 2,5282 \\
2014 & $-0,0876$ & 0,2196 & 0,0644 & 1,5527 & 2,3867 \\
2015 & $-0,1249$ & 0,2863 & 0,0528 & 1,4721 & 2,0773 \\
\hline \multicolumn{5}{l}{ Source:The Result of Processed Research Data }
\end{tabular}

The results of the Altman Z-Score Modification analysis method at PT XL Axiata Tbk in the 20112015 period showed a harmful and volatile X1 value movement, which indicates the company's liquidity experienced volatility in the 2011-2015 period. The value of X2 in this company decreased during the period 2011-2014, but experienced a slight increase in 2015, which means that the profitability of the company, in general, has decreased every year but an increase in 2015

Then, the value of X3 at PT XL Axiata experienced a significant decrease in 2011-2015, which means that there was a fluctuation in the efficiency of the company to generate revenue and operating profit. Furthermore, the value of X4 continues to decline, and this means that the value of a company in capital markets has decreased. This is considered reasonable because the company's financial performance is getting weaker and can lead to financial distress.

Meanwhile, the value of the Altman Z-Score method at PT XL Axiata Tbk, in general, is still in the health area but sometimes fluctuates in the gray area. These findings are due to the company's financial condition, especially in terms of liquidity and profitability, which are still volatile. The results are in-line with Fifrianti and Santosa (2018) conclusions. 


\section{PT Smartfren, Tbk.}

Based on the analysis of the Altman Z-Score Modification method conducted at PT Smartfren Tbk in the 2011-2015 period, the data processing results show below:

Table 3. Results of Altman Modified Z-Score of PT Smartfren, Tbk.

\begin{tabular}{cccccc}
\hline Tahun & WCTA $\left.X_{1}\right)$ & RETA $\left(X_{2}\right)$ & EBITTA $\left(X_{3}\right)$ & MVEBVD $\left(X_{4}\right)$ & Z-Score \\
\hline 2011 & $-0,1875$ & $-0,5206$ & $-0,1807$ & 0,6571 & $-3,4511$ \\
2012 & $-0,1519$ & $-0,5554$ & $-0,1118$ & 1,8351 & $-1,6312$ \\
2013 & $-0,2222$ & $-0,6617$ & $-0,1015$ & 0,7550 & $-4,2183$ \\
2014 & $-0,2687$ & $-0,7438$ & $-0,1669$ & 0,8377 & $-3,2281$ \\
2015 & $-0,2544$ & $-0,6831$ & $-0,1538$ & 0,6530 & $-3,0229$ \\
\hline
\end{tabular}

The results of the Altman Z-Score Modification analysis method at PT Smartfren Tbk in the 20112015 period showed that the X1 value, which indicated liquidity was negative and fluctuating during 2011-2015, which meant that the liquidity of the company was unhealthy. This finding reduces the company's ability to meet its short-term obligations (Subrahmanayan \& Wild, 2010; Santosa and Laksana, 2011). The value of X2 tends to be negative and fluctuates from 2011 to 2015, which means that the value of RETA (retained earnings per total asset) is in poor condition.

Then, the value of X3 in this company is also in an apprehensive condition because, during the 2011-2015 period, it always recorded negative, which means a decrease in the ability of earnings before interest and taxes (EBIT) compared to company assets. These results are due to income that tends to decrease so that its operating leverage is getting lower. Furthermore, the value of $\mathrm{X} 4$ also fluctuates with a small value, which indicates that this company experienced a decline in the eyes of investors in the capital market during the period 2011-2015. These findings are related to the company's poor financial performance so that the market price of PT Smartfren, Tbk, is getting lower. This poor performance is reflected in the value of the Altman Z-Score in this company from year to year, experiencing financial distress that has the potential to go bankrupt. This finding is following Brimantyo et al. (2013) and Fifrianti and Santosa (2018).

\section{PT Inovisi Infracom, Tbk.}

Based on the analysis of the Altman Z-Score Modification method conducted at PT Inovisi Infracom, Tbk in the 2011-2015 period, the data processing results show below:

Table 4. Results of Altman Modified Z-Score of PT Inovisi Infracom, Tbk.

\begin{tabular}{cccccc}
\hline Tahun & WCTA $\left(\boldsymbol{X}_{\mathbf{1}}\right)$ & RETA $\left(\boldsymbol{X}_{\mathbf{2}}\right)$ & EBITTA $\left(\boldsymbol{X}_{\mathbf{3}}\right)$ & MVEBVD $\left(\boldsymbol{X}_{\mathbf{4}}\right)$ & Z-Score \\
\hline 2011 & 0,2233 & 0,2069 & 0,0506 & 19,6703 & 23,1337 \\
2012 & 0,2538 & 0,2940 & 0,0856 & 23,5523 & 27,9286 \\
2013 & 0,1162 & 0,2825 & 0,0621 & 9,0626 & 11,6161 \\
2014 & 0,1128 & 0,2659 & 0,0538 & 8,5399 & 10,2621 \\
2015 & 0,0933 & 0,2227 & 0,0439 & 8,2281 & 9,2997 \\
\hline
\end{tabular}

Source: The Result of Processed Research Data

The results of the Altman Z-Score Modification analysis method at PT Inovisi Infracom, Tbk, during the 2011-2015 period showed that the X1 value in this company fluctuated and decreased during 20112015, but always recorded a value that was always positive. This result shows that the company's liquidity is well maintained so that it can carry out its short-term obligations well (Van Horne \& 
Wachowics, 2012; Fifrianti and Santosa, 2018). The value of X2 in this company increased from 2011 to 2013 but decreased slightly in 2014-2015. In general, the company's profitability is good because it always records positive values, but there is a slight decrease.

The prediction of X3 value, which is the ratio of operating profit compared to the company's assets, fluctuates with positive values during 2011-2015, this shows that the company's ability to create EBIT is quite good (Subrahmanayan, 2014). Furthermore, the X4 value associated with the company's market value is also volatile, and in 2011 and 2012 recorded a very high value. These findings show that the company's market value in the capital market is outstanding and tends to be abnormal (Bodie et al., 2014; Santosa and Laksana, 2011; Fifrianti and Santosa, 2018). Thus the Altman Z-Score for this company is excellent from year to year, so this company has no potential to experience financial problems or bankruptcy.

\section{PT Indosat, Tbk.}

Based on the analysis of the Altman Z-Score Modification method conducted at PT Indosat, Tbk in the 2011-2015 period, the data processing results show below:

Table 5, Results of Altman Modified Z-Score of PT Indosat, Tbk.

\begin{tabular}{cccccc}
\hline Tahun & WCTA $\left(X_{1}\right)$ & RETA $\left(X_{2}\right)$ & EBITTA $\left(X_{3}\right)$ & MVEBVD $\left(X_{4}\right)$ & Z-Score \\
\hline 2011 & $-0,1033$ & 0,3071 & 0,0607 & 0,8960 & 1,6721 \\
2012 & $-0,0490$ & 0,2894 & 0,0578 & 0,9782 & 2,0371 \\
2013 & $-0,1160$ & 0,2387 & 0,0277 & 0,5934 & 0,8260 \\
2014 & $-0,1309$ & 0,2276 & 0,0462 & 0,5107 & 0,8011 \\
2015 & $-0,0975$ & 0,2088 & 0,0384 & 0,4833 & 0,9538 \\
\hline
\end{tabular}

Source: The Result of Processed Research Data

The results of the analysis of PT Indosat Tbk in the 2011-2015 period with the Altman Modified ZScore method showed that the value of X1 in this company was always negative, which means that the company's liquidity during 2011-2015 was weak and therefore unable to meet its short-term obligations. Until the ratio of retained earnings to total assets (X2) looks more stable and tend to positive even though the value is insignificant. PT Indosat, Tbk is indicated to be weak in liquidity and unable to conduct internal financing due to the low portion of retained earnings.

$\mathrm{X} 3$ value analysis that illustrates the ability to operate income to total assets for PT Indosat, Tbk is quite fluctuating with a small value, this shows that the efficiency of the company's assets to produce operating profit is not good. Furthermore, for the $\mathrm{X} 4$ value, which illustrates the market value of the company, there is a tendency to decrease, which means something is not healthy enough. Meanwhile, for the value of the Altman Z-Score method, it was found that in 2011-2012 the company was in the gray area zone, which means it had the potential to experience financial distress, while in 2013-2015, the company had the potential to bear bankruptcy. The financial problems of PT Indosat, Tbk are in the aspects of liquidity and profitability. These findinds are similar with Fifrianti and Santosa (2018) conclusions.

\section{PT Telekomunikasi Indonesia, Tbk.}

Based on the analysis of the Altman Z-Score Modification method conducted at PT Telekomunikasi Indonesia, Tbk in the 2011-2015 period, the data processing results show below: The Altman Z-Score Modification analysis method at PT Telekomunikasi Indonesia, shows that the value of X1 continues to increase from 2011 to 2015. Meanwhile, Telkom's liquidity is always in a positive area and tends to 
be stable, this shows that the company's short-term financial capability is getting better and not risky . The portion of retained earnings per total asset is also high at above $40 \%$, which indicates Telkom has strong internal funding from its equity to support high business growth. Thus the company's capital expenditure will be even greater for the following years so that the company has better competitiveness.

Table 6. Results of Altman Modified Z-Score of PT Telekomunikasi Indonesia, Tbk.

\begin{tabular}{rccccc}
\hline Tahun & WCTA $\left(\boldsymbol{X}_{\mathbf{1}}\right)$ & RETA $\left(\boldsymbol{X}_{\mathbf{2}}\right)$ & EBITTA $\left(\boldsymbol{X}_{\mathbf{3}}\right)$ & MVEBVD $\left(\boldsymbol{X}_{\mathbf{4}}\right)$ & Z-Score \\
\hline 2011 & $-0,0090$ & 0,4566 & 0,2131 & 3,3781 & 6,4081 \\
2012 & 0,0347 & 0,4739 & 0,2307 & 4,0646 & 7,5911 \\
2013 & 0,0362 & 0,4905 & 0,2176 & 4,2892 & 6,2054 \\
2014 & 0,0458 & 0,5165 & 0,2066 & 4,3691 & 6,4998 \\
2015 & 0,0523 & 0,4711 & 0,1988 & 4,4227 & 6,3372 \\
\hline
\end{tabular}

Source: The Result of Processed Research Data

While the value of X3 to measure the company's ability to create operating profit (EBIT) is considered relatively stable in the range of $20 \%$ so that it is able to perform liabilities to the company's debt and print relatively high net income after tax. Furthermore, PT Telkom's X4 value is very stable and good enough as an indication that the market is valuing the TLKM shares well. Then the Altman score obtained is also quite high and stable so that PT Telkom, Tbk is considered safe from financial distress and bankruptcy. This finding is in accordance with the conclusions of Fifrianti and Santosa (2018).

\section{CONCLUSION}

Testing the Altman Z-Score Modification model conducted at PT Bakrie Telecom Tbk (BTEL) in the 2011-2015 period showed the results that the company experienced increasingly severe financial distress and led to bankruptcy. Meanwhile, PT Smartfren Tbk (FREN) also experienced financial problems similar to BTEL, so that it experiences increasingly severe financial distress during the 20112015 period. BTEL and FREN's cannot manage financial problems start with business risks properly so that the low efficiency caused decreasing income and increase the industry competitiveness. Thus the operating income of the two companies continued to decline, resulting in cash flow and liquidity difficulties. The longer the solvency of these companies is also lower so that the ability to meet their long-term obligations is getting smaller and consequently triggering capital structure problems that can bankrupt both.

As for PT Indosat, Tbk starts experiencing financial distress during the period 2011-2015, which is caused by liquidity problems, profitability as well as lower solvency. However, Indosat's problems are not as substantial as BTEL and FREN because they only experienced the initial financial distress. Testing for PT XL Axiata, Tbk is considered quite safe and healthy but has the potential to experience financial distress with conditions similar to Indosat. These results are due to the lower ability of working capital and liquidity due to the continued decline in the company's operating profit.

Meanwhile, PT Inovisi Infracom Tbk in 2011 and 2012 have a very high Z-score making it safe from financial distress. However, the high value of the Z-score of this company is contributed by abnormal stock prices, thereby creating risk in the future. In this case, the investor needs more careful with this company. Furthermore, PT Telekomunikasi Indonesia has no potential financial problems in terms of liquidity, profitability, efficiency, and solvency during the period 2011-2015. Adequate 
revenue and EBIT support make the company's liquidity and cash flow sufficiently reliable so that its solvency is well maintained.

\section{Limitations and avenue for future research}

This study has two limitations, namely the scope sector discussed only in the telecommunications industry and only uses one prediction model, the Altman Modified Z-Score. For further research it is recommended to compare various sectors / industries and use other prediction methods such as Springate, Ohlson and others.

\section{Acknowledgements}

Thank YARSI University for providing the facilities and tools to conduct this study. The award was given to colleagues and reviewers who have provided valuable critics and input for this article.

\section{REFERENCES}

Altman, E. I, Danovi, A. and Falini, A. (2012). Z-Score Models' Application to Italian Companies Subject To Extraordinary Administration.

Altman, Edward I. (1968). Financial Ratios, Discriminant Analysis and the Prediction of Corporate Bankruptcy, Journal of Finance, 589-609.

Ayu, N., 2008, Perbandingan Analisis Prediksi Kebangkrutan Menggunakan Model Altman Pertama, Altman Revisi, dan Altman Modifikasi Dengan Ukuran dan Umur Perusahaan Sebagai Variabel Penjelas, Jurnal Siasat Bisnis, 13(1).

Brimantyo, Harril. et.al. (2013). Penerapan Analisis Altman Z-Score Sebagai Salah Satu Alat Untuk. Mengetahui Potensi Kebangkrutan Perusahaan Pada Perusahaan Telekomunikasi yang Listing di BEI Periode Tabun 2009-2011. [Tesis], Malang: Universitas Brawijaya.

Fanny, M. and Saputra, S. (2000). Opini Audit Going Concern: Kajian Berdasarkan Model Prediksi Kebangkrutan, Pertumbuban Perusabaan, Dan Reputasi Kantor Akuntan Publik. (Studi Pada Emiten Bursa Efek Jakarta). SNA VIII. Solo. 15-16 September.

Fifrianti, R. and Santosa, P. W. (2018). Prediksi Kebangkrutan Model Springate pada Industri Telekomunikasi, Journal of Economics and Business Aseanomics, 3(1),

Purnajaya, D. M., Komang and Merkusiwati, N. K. (2014). Analisis Komparasi Potensi Kebangkrutan Dengan Metode Z - Score Altman, Springate, Dan Zmijewski Pada Industri Kosmetik Yang Terdaftar Di Bursa Efek Indonesia . Bali: Universitas Udayana.

Kuncoro, A. W. (2011). Analisis Kebangkrutan Dengan Model Springate dan Zmijenski Pada PT Betonjaya Manunggal Tbk. Periode 2007-2011. Jakarta: Universitas Budi Luhur.

Kurniawanti, B. A. (2012). Analisis Penggunaan Altman Z-Score Untuk Memprediksi Potensi Kebangkerutan perusahaan Makanan Dan Minuman yang Terdaftar Di BEI Periode 2007-2011. [Skripsi], Jakarta: Universitas Gunadarma.

Lukviaman, A. S. (2009). Perbandingan Analisis Prediksi Menggunakan Model Altman Pertama, Altman Revisi, dan Altman Modifikasi Dengan Ukuran dan Umur Perusahaan Sebagai Variabel Penjelas (Studi Pada Perusahaan Manufaktur Yang terdapat di Bursa Efek Indonesia). Jurnal Siasat Bisnis, 13(1),

Saifi, M., Farah, D. and Mastuti, A. F. (2013). Altman Z-Score Sebagai Salah Satu Metode Dalam Menganalisis Estimasi Kebangkrutan Perusahaan. [Skripsi], Malang: Universitas Brawijaya.

Peter, Y. (2011). Analisis Kebangkrutan Dengan Metode Z-Score Altman, Springate dan Zmijewski Pada PT.Indofood Sukses Makmur Tbk. Periode 2005-2009.

Rahmawati, A. Y. (2010). Kebangkrutan Perusahaan Menggunakan Model Altman dan Zavgren Pada Perusahaan Food and Beverages. Jurnal The Winners, 11 (01). 
Santosa, P. W. (2010) Longterm Trends Analysis of Managing Expectation for Active Value. Jurnal Akuntansi dan Keuangan. 12(2), 94-115

Santosa, P. W. and Laksana, H. Y. (2011). Value at Risk, Market Risk and Trading Activity: CAPM Alternative Model, Journal of Applied Finance and Banking, 1(4), 239.

Santosa, P. W. and Hidayat, A. (2014). Riset Terapan: Teori dan Aplikasi, Penerbit Globastat, Jakarta.

Santoso, I. S. (2011). Analisis Kebangkrutan Dengan Menggunakan Metode Springate, [Skripsi], Bandung: Universitas Kristen Maranatha.

Saputra, M. F. (2000). Opini Audit Going Concern: Kajian Berdasarkan Model Prediksi Kebangkerutan, Pertumbuban Perusahaan, dan Reputasi Kantor Akuntan Publik (studi Pada Emiten Bursa Efek Jakarta). Solo.

Sawir, Agnes. (2001). Analisis Kinerja Keuangan dan Perencanaan Keuangan Perusahaan. Jakarta:PT Gramedia Pustaka Utama.

Springate, Gordon L.V. (1978). Predicting the Possibility of Failure in a Canadian Firm. M.B.A. Research Project, Simon Fraser University. January.

Subrahmanayan, K.R and Wild, John, 2010, Financial Statement Analysis, Mc Graw-Hill Education, USA.

Sukhemi. (2004). Analisis Rasio Kenangan Untuk Memprediksi Kebangkrutan. Jogjakarta: Universitas PGRI Jogjakarta.

Supardi. (2003). Validitas Penggunaan Z-Score Altman Untuk Menilai Kebangkrutan Perusahaan Perbankan Go public Di Bursa Efek Jakarta. Bandung: Universitas Padjajaran.

Syamsul, A. A. (2008). Pemiliban Prediktor Delisting Terbaik (Perbandingan Antara The Zmijewski Model, The Altman Model, dan The Springate Model. [Skripsi], Jogyakarta: Universitas Islam Indonesia.

Tribun News. (2014). Merger dan Akuisis Selamatkan Axis dari Kebangkrutan. http://www.tribunnews.com/bisnis/2014/02/17/merger-dan-akuisisi-selamatkan-axis-darikebangkrutan. (22 Desember)

Van Horne, J. and Wachowicz, J, 2009, Fundamental of Financial Management, Ed. 13th, Prentice-Hall, USA

Zmijewski, Mark. (1983). Predicting Corporate Bankruptcy: An Empirical Comparison of the Extant Financial Distress Models. Working paper. SUNY at Buffalo. 